\title{
SUSTAINABLE BEHAVIOR - THE NEED OF CHANGE IN CONSUMER AND BUSINESS ATTITUDES AND BEHAVIOR
}

\author{
Grażyna GIERSZEWSKA*, Marek SERETNY** \\ *Warsaw University of Technology, Faculty of Management, POLAND \\ e-mail: grazyna.gierszewska@pw.edu.pl \\ **American University in the Emirates, College of Busines Administration, \\ Dubai, UNITED ARAB EMIRATES \\ e-mail: marek.seretny@aue.ae
}

\begin{abstract}
Today's economy is experiencing serious economic and social problems affecting all world citizens. The earth seems to have become insufficient in meeting the standards of living that societies expect. The classic marketing approach is seen as the cause of many problems. It has contributed to the emergence of the behaviors that should be changed. With its indisputable impact on development, marketing has influence on degradation, but it can also build positive customers, organizations, and behaviors. Understood as a philosophy, a way of thinking and doing business, sustainable marketing, which we are interested in, promotes responsibility, conscious consumption, relationships, and sensible business. It is interesting to understand what the generation of young people thinks about the issue the generation that will manage enterprises in the next few years and create global consumption. In this article, we present a research project aimed at answering the question "is today's young generation ready to face the challenge of changing their lifestyle based on unlimited consumption for the one that will take sustainability into account as a basis for consumer behavior?".
\end{abstract}

Keywords: sustainability, sustainable mindset, management, consumer marketing, customer retention, market research, advertising, sustainable consumption, freeganism, sharing economy, business economics, responsible consumption.

JEL: M31, A11, Q56.

1

\section{Introduction}

Al Gore (Former US vice President) in 2008 stated;

"The age of sustainability has arrived, but now we must drive it fully through our socio-economic system. To do so, markets (customers as well as businesses) will have to continue to evolve to take into account the full environmental and social externalities of business... This shift will require nothing less than a complete change in mindset - one that views our planet as a long-term investment, rather than a business in liquidation" (Gore, 2008, p. xxv-xxvi).

There are many reasons and arguments that can support responsible management and the need to verify the view that profit maximization is the main purpose of the business. The order in which they are discussed in this article does not indicate their ranking with regards to importance.

The development of participative democracy and civil society, combined with the use of modern in- formation technologies and communication, and the intensification of social movements for the protection of rights in various socioeconomic areas increasingly affect business. The relationship between the company and the local community as well as the whole society is changing, not to mention the need to verify their approach to employees. The necessity to conduct business in accordance with ethical values is increasing. But perhaps the strongest pressure on enterprises is exerted by clients, both individual and institutional.

Changes in public procurement, legal regulations, and various standards; increase in socially responsible investments; and, in addition, the expectations of employees influence the fact that there is an augmented interest in responsible management. Enterprises, wanting to keep up with the change in the role of management in the new situation, communicate their values and become their personification in the eyes of customers and other stakeholders by imple- 
menting the concept of sustainability. They communicate how they fight poverty, initiate sociocultural changes, and influence the protection of the natural environment. They also analyze the impact of value-based management on employees, partners, or shareholders.

Here, the main objective is to make the world better through shared responsibility and respect for the common good. Greater market awareness requires emphasis on internal values, spirituality and culture, and more intensive cooperation with customers (Grudzewski, et al., 2010).

In confrontation with the principles of social responsibility, managers, business leaders, and entrepreneurs face the following important questions: how to combine moral values that underlie responsibility with everyday business life? How do you confront values with reality so that they do not just remain lifeless instructions?

\section{Enterprise responsibility}

Accepted by science, but mostly in market practice, often indisputably, the imperative of economic growth by all means and consumption egoism leads to the abusive exploitation of limited natural resources and is an example of irresponsibility for the future of the next generations and future of our planet.

In academic and increasingly economic as well as political spheres, the issue of changing the current expensive and unstable model, based on greed consumption to the model of sustainable consumption in which consumers prudently use goods, showing moderation and responsibility towards future generations, is being discussed.

Many companies have found a source of excellent businesses in societies that have been sensitive to environmental protection. It is worth acting in such a direction that they become creators of responsible development.

Contemporary human civilization has achieved such a level of comfort that is possible to maintain only on the condition of proper management and development of relations:
- between economic growth and care for the natural and artificial environment created by mankind,

- between quality of life and human health,

- between economic calculation and social justice ${ }^{1}$.

The key concepts of the theory of sustainability are the concept of basic needs, the idea of limited options, and the endurance of the global ecological system.

Economic growth should lead to increasing social cohesion and reducing social stratification, equalizing opportunities, preventing marginalization and discrimination, improving the quality of the environment, and including limiting the harmful impact of production and consumption on its condition and conservation of natural resources.

Economic growth should lead to increasing social cohesion and reducing social inequalities, providing equal opportunities, preventing marginalization and discrimination, and improving the quality of the natural environment by limiting the harmful impact of production and consumption.

The principle of intergenerational justice is also emphasized, that is taking into account the interest of future generations in the implementation of the "here and now" growth.

The category of responsible business development is very spacious and includes:

- Business ethics - moral practices in the economy. Despite the fact that many companies treat business ethics as "a square peg in a round hole," it becomes an important aspect of business behavior.

- Corporate social responsibility (CSR), which assumes voluntary enclosure of social and ecological aspects by enterprises in their activities and goals, and building ethical relations with stakeholders, including those "silent," that is the natural environment.

- Triple Bottom Line (TBL) of sustainability assumes that the success of organization is influenced by its achievements in three dimensions:

\footnotetext{
${ }^{1}$ This is the first sentence from the World Commission on Environment and Development report of 1987 "Our common future" called the Brundtland Report. Gro Harlem Brundland is the former prime minister of Norway, very active in promoting environmental protection principles.
} 
economic, ecological, and social. The author of TBL is Freer Spreckley, but John Ellington "made it famous" (Spreckly, 1981) ${ }^{2}$.

The benefits of responsible business management should be considered in the long-term perspective, and they include:

- Increased interest of investors who are more and more interested in cooperation with responsible companies, achieving not only good financial results but also that are managed in a transparent manner and building a responsible image and relations with the environment. For many investors, the company's financial credibility depends on its social credibility.

- Increasing the loyalty of consumers (customer retention) - the increase in consumer's social awareness causes that in their purchasing choices they base on trust in a given company and its image. The growing group of consumers draws attention to the "ecological" nature of the product and compliance to the principles of social responsibility in the process of production.

- Improving relations with the community and local authorities - the company's participation in the life of the local community, making longterm and measurable social investments, facilitates its smooth and peaceful functioning. Social responsibility enables it to become firmly rooted in the community and win the favor of its residents as well as to gain the acceptance of local authorities.

- Competitiveness - introduction of sustainable business principles is an asset that helps companies gain a competitive advantage. For Polish organizations, transparent CSR policy can be one of the ways to build its position in international markets, where expectations regarding compliance with standards of sustainability are more obvious.

- Raising the level of the company's organizational culture - by facing the challenges of social responsibility, the company raises its standards of dealing with stakeholders (employees, contrac-

\footnotetext{
2 The concept was introduced by J. Ellington into practice as a result of the work of the Brundland Commission, in which he participated.
}

tors, clients) and thus avoids the costs of "bad partnership." It influences the shaping of the company's organizational culture based on trust, responsibility, and transparency for all interested parties.

- Shaping a positive image of the company among employees - corporate social responsibility is an important element of the non-financial motivation of employees. Thanks to ethical codes, social programs or care for the environment, the image of the company is improved in the eyes of the employee. Employees with greater appreciation refer to the functioning of the company seeing that part of its activity is aimed at solving important - also for them - social problems.

- Employment and retention of best employees when the company's image is improved and the trust among employees increases, the company's attractiveness in the labor market also increases, which allows attracting new and retaining the best employees.

Every managing person in the economic, social, and political sphere, whether he or she wants it or not, is responsible for the impact that the organization has on the outside world. Therefore, it is a very important for managers to perceive and anticipate the social, economic, and environmental effects of the activities of the organizations they manage.

Unfortunately, despite the existing legal regulations and social pressures, many businesses in the recent years are perceived as the perpetrators of social, environmental, and economic problems, leading to crises unprecedented in such dimensions in the history of capitalist development. This is a consequence of the business concept that has existed for decades, which sees market activity narrowly, primarily through the prism of financial results and running business at the expense of society, and not for the benefit of society.

Of course, the financial result is a very important element of the market activity, which must not be ignored, but the profit should be a consequence of consumer satisfaction not the main business goal. This situation requires that businesses, and above all their leaders, should regain trust and rebuild relationships with all market participants on which they con- 
duct their activity by proposing a new business model based on responsibility.

In order to better understand the phenomena that creates business responsibility in the context of the functioning of the enterprise, which takes into account the network of dependencies and connections between the organization and its environment (groups of closer and further stakeholders), it is worth analyzing these activities in terms of its systemic functioning.

Therefore, there is a need to build business models based on the cooperation of the organization with the market and social environment in which the interdependence of network of connections is of fundamental importance for effective management of the organization's relations with its stakeholders.

\section{New social trends}

An example of a strong social trend with a global dimension is the creation of a new quality of life "healthy life" - healthy conditions for human functioning, a trend that was described as a great social movement of the 1970s and 1980s. New business and service areas were created that produced healthy food, clothing, and sports equipment.

Whole industries have been reborn to meet just such customer needs. Social changes have resulted in the creation of new products in health care, pharmacy, and tourism. Aware of the dangers arising from the use of "non-ecological" products, consumers began to pay attention to what they buy and in which environmental conditions they live and work. The tobacco industry fell into a serious crisis, and the entire chemical industry was forced to implement pro-ecological production technologies. The rules of functioning of entire areas of the economy have changed.

New patterns of consumption and consumer behavior have multidimensional effects. Travel could be an example. In a country like Poland, where people have not been able to travel to numerous interesting places visited by tourists for many years, the boom of traveling to exotic places has been observed for many years. It is benefited by companies organizing such trips, air carriers, and also insurance com- panies, whose revenues are growing at a rate of more than $100 \%$ annually (e.g., travel insurance).

Particularly among the middle class, a model of consumption prefers spending holidays on foreign trips and weekends in their own countryside homes. New consumption patterns also result in attention to stylish home furnishings, cultural entertainment, good education of children, and retirement provision. This creates opportunities for the development of many industries and sectors and also for promoting responsible consumption.

Globalization causes the universalization of consumption patterns and the so-called phenomenon "Californization of needs." People watching the same "television program formats" on all continents and buying the same products from global producers on local markets, are beginning to look similar and behave similarly in all corners of the world.

Regardless of the place of residence and the level of wealth, everyone wants to live like in California shown on TV. This is for companies, on the one hand, an incentive for globalization, and, on the other hand, it forces the business to lower prices and increase the scale of production.

The fact that the customer has a choice between a "global product" and a "local one" is positive, but it must be remembered that the promotion of responsible management and responsible consumption patterns is not neglected at the same time. Of course, the new trends also have "their opposites." Such phenomena are freeganism and prosumption.

Freeganism $^{3}$ is an anti-consumer lifestyle based on limiting participation in conventional economics. Freegans rely on the community they create; they preach generosity, freedom, cooperation, and sharing - as a contrast to a society based on materialism, moral apathy, competition, conformism, and greed. This ideology, along with the rise of trends for environmental protection, has become so popular in Western Europe that even a special city guide for freegans was created in Barcelona. Polish repre-

\footnotetext{
${ }^{3}$ The name of this movement was created in the United States as a combination of words - free and veganism - however, not all of its members are vegans or vegetarians. [online] Available at: https://pl.wikipedia.org/wiki/freeganizm [Accessed 20 April 2016].
} 
sentatives of this ideology (and at the same time the lifestyle) also use the terms container shippers.

Freeganism includes searching for food already thrown into the garbage as well as asking for goods before they are thrown away by restaurants, marketers, or hypermarkets. Freegans consider themselves as a subculture that changes lifestyle and social contestation, and an example of the development of new values in a globalized world. Who is the statistical freegan? Usually, they are young people between the ages of 20-30 years, they are studying or graduates, and they often get involved in different social activities. While in the United States and in the west of Europe, the phenomenon sometimes includes even whole families, in Poland, freeganism remains much more alternative and niche.

Freeganism is part of the sharing economy. The sharing economy consists of using and sharing what we have to provide different services to each other. A place in someone else's car to go on holiday, rent your own apartment when you are not there, and money borrowed online.

The sharing economy is known from old times but before the era of the Internet, it was only a margin and was the result of close relationships. At present, the phenomenon has gained wider significance, as evidenced by the emergence of organizations such as the Uber Corporation, Airbnb, or crowdfunding, as a form of project financing by the community.

\section{Consumerism}

Consumption in its extreme form of overconsumption or even hyperconsumption is becoming one of the main problems of the globalized world (The Economist, 2012). Consumerism is most often understood as excessive consumption of goods and services, unjustified by real human needs and not taking into account social, ecological, and individual costs.

It is criticized not only for the fact that it promotes the development of materialism but also a great waste of produced goods, human labor, and nonrenewable natural resources and also because it contributes to the spiritual degradation of man, drawing man into addiction to material goods. At the same time, traditional values characteristic of many societies is being pushed behind and replaced by the hedonistic attitude to life, expressed in the maxim of carpe diem (Mróz, 2009).

In connection with the above, business management, especially the role of marketing, takes on a new sense and in view of the need to create responsible consumption.

Sustainable management as a new concept is to recreate its assumptions, theories, tools, and systems in order to enable making the right business decisions. Managers, aware of their responsibility, should use management tools in such a way that they effectively move from the paradigm of sales expansion to creating conscious and responsible consumption and, finally, to create and promote new values and raise living standards by influencing responsible production.

More and more enterprises, large corporations, and local companies understand that old management rules are not very successful, and they are also convinced that they have to reach conscious, using technological achievements clients. In addition, the business is more and more aware that the products and services offered are the result of a corporate culture that inspires consumers and reflects their values.

The customer becomes not only a consumer but also a co-creator of the product - to highlight this situation, the new word "prosumer" is used (Szymusiak, 2015). Consumers choose products and services that meet their deeper need for creativity, idealism, and integration with the community. They realize that their buying power has a global impact, which affects their behavior and willingness to exchange opinions on the choices made. The latest approach to the client explains how to use social discussions, position the brand as a positive force changing the world, and cooperate with consumers who become advocates of the brand.

Prosumption $^{4}$ is defined as the activities creating value that the consumer undertakes, and as a result,

\footnotetext{
4 Prosumer - professional/producer + consumer - a mixture of words - a professional / producer and a consumer - a consumer involved in co-creating and promoting products of a favorite brand or the simultaneous production and consumption
} 
a product is created, which ultimately is consumed by the customer, and these activities become consumer' new product experiences. This is a new, interesting phenomenon causing the blurring of the existing division on the market into the production sphere and the consumption sphere.

Individual or organized groups of prosumers participate in the activities of producing a product intended for their own use. The prosumer is a participant of the prosumption process; hence, the user/consumer is who makes the product to consume it on his or her own, in other words a product made for his or her own use. As a result of the prosumer's activity, a material product, a service, as well as an idea can be created.

The most well-known examples of prosumption are sharing knowledge in the Wikipedia database, creating open source software, and improving existing products through social networking. Prosumers have a broad knowledge of the products they are interested in. They use this knowledge when making purchasing decisions and are also willing to share it with others. They try, especially through the Internet, to actively participate in creating and promoting the products of their favorite brand. The activity of prosumers is also visible in the area of sustainable development, and in particular environmental protection.

The notion of prosumerism is also used as a set of social behaviors and prosumer attitudes that recognize the maximization of functional as well as intangible benefits as the determinant of product value. Social and political prosumerism can also form the basis for creating a new kind of socioeconomic and political order, creating an alternative to existing solutions (Szul, 2016).

Do not confuse the term of prosumption and customer focus, which means that the customer can freely modify and adapt the product to their private needs,

of goods and services. Initially, the concept of "prosumer" was only a combination of the terms producer and consumer. The concept of "prosumption" first appeared in 1972, when Marshall McLuhan and Barrington Nevitt put forward the thesis that with the development of new technologies, the consumer may increasingly become a producer. It was not until 1980, however, that the term was introduced by Alvin Toffler, writer and futurist. [online] Available at: www.socialnety.pl [Accessed 23 April 2016]. for example, by "assembling" elements of a car or computer equipment. This is not much different from the traditional marketing strategy.

However, prosumption testifies about shifting boundaries between production and consumption. The development of prosumption is connected and is the result of the dissatisfaction of consumers with massive and standardized production. Prosumption thus influences the creation of a new organization and style of work as well as life, and consumption is an inseparable element of this phenomenon. Prosumer is a new kind of consumer who is not limited to simply buying a given product - he or she expects something more. To adjust the market to such needs, the "rules of the management game" should also be changed.

Sustainable management not only addresses consumer relations but also discusses how the company defines its values and becomes their personification in the eyes of the rest of the stakeholders. Describes how brands based on ethical values fight poverty, initiate sociocultural changes, and affect the protection of the natural environment. Value-based management affects employees, partners from distribution channels, and shareholders.

Of course, responsibility should not only refer to production standards, because the responsibility for the final effect of any work, which is a product or service, is only one of the effects of responsible management. What's more, responsibility applies to everything that surrounds us, thanks to which we achieve the quality of our existence.

In enterprises that think in terms of responsible management, they cover everything from suppliers to the final customer receiving the finished product. It covers the entire organization and business management, the more that responsible management becomes a very effective tool for shaping the competitive advantage.

Responsibility is both a philosophy and a management method aimed at achieving stable growth and development of the organization through the involvement of all employees in the production of the value that clients expect. In other words, a complex system of sustainable management is an approach of the management focused on the responsible activi- 
ties with the involvement of all employees of the company.

This applies to the most responsible action carried out by managers at all levels of management from the chief executive to the lowest management. Its goal is to achieve long-term success by obtaining customer satisfaction for the benefit of employees, society, the natural environment, and the business itself.

The growing cooperation of consumers, using social media and mobile technologies, has a great impact on marketing. People managing it are no longer able to fully control messages that build the image of their market offering. Marketers have to cooperate more and more with influential and powerful consumers than ever.

Future consumers are involved in creating new products and services that will meet their needs, discuss and evaluate price proposals, and also contribute to the evaluation and creation of advertising proposals.

Consumers are becoming the most important element of new solutions. Trying to satisfy their needs and eliminate worries and problems, thanks to which the world will become better, consumers are no longer only passive recipients for marketers but become people with a heart and soul (Kotler, et al., 2010).

In an uncertain world, customers are looking for companies presenting values that express goals that meet their deepest desire for social, economic, and environmental justice. In addition to expectations that meet their requirements in terms of functionality and emotionality, the offer must satisfy their internal-spiritual needs. In many cases, sustainability has a chance to emerge, thanks to changes in consumer habits in the broad sense.

In addition to changes in the way of shopping, people are currently beginning to change their lifestyle as a whole. Recycling, composting of waste, and alternative ways of traveling become a standard. Responsible marketing plays an important role in this process. The key aspect of marketing has always been understanding the impact of and change in consumer behavior, so this discipline becomes an ideal sphere for developing social changes that will pro- mote responsible consumption and, in a broader sense, a sustainable lifestyle.

Is responsible consumption possible? What do young people think about it?

Naturally, in one research project, we are not able to answer all the questions related to responsible production or consumption. In the research project, presented in this article, authors try to understand if we are really dealing with the situation of widespread consumption egoism in the current young generation, which is the cause of many problems on a global scale, and whether this phenomenon may jeopardize the development opportunities of future generations?

\section{Opinions of young people about responsible consumption}

The first question that the authors asked themselves is: Do the young people we study fit into the generation of YOLO (you only live once)?

Generation YOLO are young, well-educated, wellexperienced, multilingual, oriented in new technologies, multitasking experts, easily adapting to changes, innovative, and also impatient. The Millennium generation has a natural talent for cooperation, but also a new qualitative view of the world, the system of values, and goals.

They are people focused on self-development, escaping from the current framework of professional space. They put a lot of emphasis on finding a job that will give them a sense of personal fulfillment. They find themselves better in companies with a flat hierarchy; they do not accept bosses! They value work-life balance more than anything! They want their professional activity to create new friendships, acquire new competences, and give them the opportunity to participate in the pursuit of a higher goal.

Are these young people ready for the challenges of responsible consumption?

\subsection{Responsible lifestyle and consumerism in the opinion of young people}

During the conducted research, many questions were asked and the answers to which were to determine 
whether the generation of young people aged 20-25 years is ready to face the challenges of changing their lifestyle based on unlimited, often irresponsible consumption for responsible, conscious consumption.

The research was of both qualitative and quantitative nature. Qualitative research has been carefully prepared; it consisted of a multi-stage procedure of focused analyses. A total of 116 international Master's students from Warsaw University of Technology from Azerbaijan, India, Russia, France, Peru, Spain, and Poland participated in the research.

\subsection{The qualitative research}

The qualitative research was divided into stages in which topics related to responsibility and its various dimensions were discussed:

- The first stage was to familiarize respondents with the goals of the research, getting to know the participants, and encouraging the exchange of views.

- The second stage is getting to know the lifestyle, habits, and everyday habits of the respondents. A collage technique was used to illustrate the motives of behavior and values that are important in a young person's life.

- The third stage is general discussions about brand.

- The fourth stage was a discussion about responsible consumption.

- The fifth stage was to check whether students notice connections between their own choices and the consequences in the future.

- The sixth stage addresses the problems of running a business in Poland. The aim was to get to know the respondents' opinions on the ways in which entrepreneurs behave.

- In the seventh stage, participants were introduced to the sustainable marketing model in order to assess its attractiveness, adequacy in relation to current global market events, and its usefulness in relation to the specificity of the Polish market.

- At the eighth stage, there was a discussion about corporate social responsibility. The aim was to check whether students can see the benefits of be- ing responsible in business and whether they realize that this is a way to achieve a competitive market advantage.

- The ninth stage was to get acquainted with the students' opinion on state intervention, as the legislator in the responsibility of citizens. The aim was to answer the question whether, if legal regulations would limit irresponsible behavior and thus problems arising as a result of excessive and irresponsible consumption would be lesser.

- The aim of the 10th stage was to get to know the students' opinions on the proposed educational activities and to check whether educational programs run by various educational organizations reach them and are noticed by them.

In the summary of the study, the essence was a reflection on the need to change the lifestyle, promote healthy habits, and consider the ways of controlling producers.

\subsection{The conclusions from focused studies concern}

The conclusions from focused studies concern are as follows:

- sustainable consumption,

- perceived market practices,

- ways of conducting business in the future by respondents,

- the impact of government institutions on the responsibility of young citizens,

- the role of education in conducting responsible business activities,

- ethical business.

Responsible consumption and responsible management according to students have many dimensions such as rational decision making and buying products of local producers, which is considered as modern patriotism. Responsible consumption also has very specific dimensions - checking what we are buying, saving and balanced shopping, paying attention to the price - by default, whether we receive adequate value for money.

Young people had no illusions about common business practices - moving production to countries in the Far East Asia, where children are often em- 
ployed in factories and people are very poorly paid for their work. They also see that it is difficult for them to change their consumption habits often simply out of laziness or conformism. Quite common were the opinions that changes require collective or maybe even massive actions, because the individual is unable to cope with the problems.

Is this tantamount to an excuse that if I cannot do anything, I do not have to do anything at all?

Students asked how they would run their own business are very ideological and "correct." They would employ young people; they would produce in their country, that is, they would not transfer their factories abroad and production would have to meet ethical and ecological norms; and as entrepreneurs, they would join charitable activities. Students participating in the qualitative study believed that state interference in the activities of enterprises are unnecessary, and even harmful, the role of the state is to educate about responsible management, responsible consumption, and ecology.

When they would run a business, they want to be responsible for their decisions, should act based on the binding moral and legal principles, and should not be subject to constant regulation and changes of regulations. They also indicate the need to reduce bureaucracy - this postulate appears from the beginning of the transformation in Poland and is indicated as a barrier to development on the occasion of almost every research conducted in enterprises.

Young people participating in focus studies had a lot to say about the role of education for responsible consumption. They not only see its necessity but postulate its forms, recipients, and levels. Education should be from early school years and education through play is good, but adults also need to be educated. Respondents emphasize the important role that various media play on education.

Very interesting views were given by students on what ethical business means. They paid attention to obvious matters - namely, that it is worth taking care of the environment, because the penalties for its destruction are very high and it simply does not pay off.

An ethical organization means a chance for development, more clients, and a high competitive posi- tion. An ethical company treats employees well, and this can give the company a long-term advantage and less employee fluctuation, perceiving the organization as a good employer and identifying employees with the company's goals.

\section{Conclusions resulting from qualitative focused studies}

Conclusions resulting from qualitative focused studies are quite optimistic:

- The YOLO generation ${ }^{5}$ appreciates many values and believes that the life of every human being is shaped by relationships with other people, life in harmony with nature, enabling one to realize oneself. They believe that one cannot neglect the need for order and peace of life, physical activity, and healthy consumption.

- Young people are aware of their weaknesses and the need to fight them - justifying bad habits with lack of time, smoking cigarettes, and procrastination. They are also aware that some of their behaviors have a negative impact on the environment.

- Young people see the need for constant education (children, adults in various forms) and increasing knowledge about the dangers of irresponsible consumption. At the same time, they are able to justify their behavior that violates the principles of responsible consumption with a lack of knowledge. Changes require the involvement of the whole society, not just individuals.

- Students understand the need to change their consumption habits; they see the problem of consumptionism but do not see the sense of the individual's efforts to improve the situation, and only the involvement of the whole society has meaning and can make a difference.

The quantitative survey was conducted in January to February 2018 in the same age group of young people aged 20-25 years. However, this time only the Poles were respondents. The number of respondents was 579; CAWI method and online interviews were used.

\footnotetext{
${ }^{5}$ This term is consciously used, although it may be exaggerated and somewhat symbolic.
} 
The aim of this study was to approximate and quantify the problem of responsibility from the perspective of young people:

- getting to know current habits and awareness regarding responsible consumption,

- getting familiar with the needs and possibilities of changing consumption habits into more responsible ones,

- defining the meaning of responsible consumption.

Are young people happy with their lifestyle?

In the study, we identified four groups of respondents:

- searchers-experimenters who are satisfied with their lifestyle, which does not mean that they are not ready for change $-65 \%$,

- searchers-dissatisfied - ready for changes, because they are dissatisfied with the current state $18 \%$,

- conservatives-satisfied, reluctant to change their lifestyle $-12 \%$,

- unhappy but not ready for change $-5 \%$.

Searchers-experimenters are the largest group of young people who are open to changes in their lives, which results from the awareness of responsibility and rational consumption. The vast majority of them (80\%) think that choices should be made knowingly when shopping, and $76 \%$ are willing to pay more for the products of companies managed responsibly, but only $18 \%$ think that responsible consumption is the use of products produced by companies operating responsibly.

Searchers-dissatisfied - the majority of the respondents in this group (82\%) agree on the necessity of responsible consumption, but less respondents $(63 \%)$ are ready to pay more for the products of responsible companies, and only a small group (14\%) thinks that responsible consumption means using from products of companies operating responsibly.

Conservatives reluctant to change because they are satisfied with their way of life, they surprise with their opinions about responsible consumption - they understand what it means, they are willing to pay more for products produced by responsible organizations.
Dissatisfied, but not ready for change, also fits into conscious consumers - most of them $-60 \%$ understand the essence of responsible consumption and $48 \%$ are ready to pay more for the products of companies operating responsibly.

What else does responsible consumption and sustainable management mean for young people:

- being well informed about what I am buying,

- responsible consumption is making purchase decisions, taking into account all the consequences of raw material extraction, production, distribution, use, and utilization of the product,

- the proper selection of goods and services compared to their price - meaning rational buying, products currently needed for consumption, not generating artificial demand,

- companies treat their employees as people, not as cheap labor,

- caring for the natural environment during production.

\section{Conclusion}

Consumerism is closely connected with the idea of responsible consumption, which can be understood as an interpretation of the concept of responsible development in relation to the area of consumption.

The essence of responsible development is to ensure continuous and relatively permanent improvement in the quality of life of present and future generations by shaping proper management in three spaces: economic, social, and the use of natural resources. Therefore, it is a development whose important component is the integration of the life quality (Dąbrowska and Janoś-Kresło, 2009, p.52).

The issue of life quality, considered in the context of responsible development, involves the need to change ones mindset and the philosophy of life the recognition of new values and lifestyles and the different shaping of living conditions.

Responsible consumption means the use of goods and services that is responsible for meeting the needs that improve the quality of life, but with two conditions (Dąbrowska and Janoś-Kresło, 2009, p.53): 
- achieving these objectives will be accompanied by a simultaneous drastic reduction in the use of natural resources and energy as well as reduction of emissions to the environment, including discontinuing usage of toxic materials;

- gaining a better quality of life for present generations will not become an obstacle for satisfying the needs of future generations.

Responsible consumption practically means making purchase decisions taking into account social and environmental consequences that result from the extraction of raw materials and the production, distribution, use, and utilization of a given product or its packaging. It also means a change in the approach to shopping. What we buy and how we buy is directly related to the development of many societies - it can accelerate or obstruct development. The low cost of the product may be the result of the manufacturer's failure to comply with many standards. Overconsumption in developed countries, contributing to the unjust distribution of goods and distribution of global resources, hinders the development of countries referred to as Third World countries.

Food, clothing, cosmetics, cleaning products, water, energy, gasoline, and services are bought every day. For each of these goods, the consumer pays a certain amount of money. Responsible (conscious) consumption can also mean looking at the money we have from a different perspective. You can look at it as an electoral voice by which the consumer advocates for or against a particular attitude of the company.

Even small everyday purchases of products such as coffee, tea, cereals, and garbage bags are our private "votes." The purchase of organic food means voting for environmental protection, and the purchase of a product from the Fair-Trade area is a statement of support for respect for human rights (Huma, 2013).

When deciding about the purchase of a given product, the consumer advocates a company that responds positively to the following questions:

- Who and under what conditions produced it?

- What material and in which process was it made?

- How it is used and its affect the natural and social environment?
- Does its purchase have a negative or positive effect on the development of the Third World countries?

The YOLO generation we have been researching already understands many of these problems and is able to answer these questions.

Is responsible consumption possible? The question should be asked differently, perhaps more precisely: is it possible in the contemporary world to reconcile the values underlying the responsible consumption and consumer lifestyle on which the development of the global economy is based?

This is indisputably a challenge for responsible management and marketing. It involves activities that change awareness and promote a responsible lifestyle, and this is possible through educational marketing activities. It is important, therefore, that education is conducted from an early age. It should be conducted both in the school system and by social and consumer organizations but above all by responsible business.

The challenge concerns the possibility of changing consumer habits that would contribute to a change in lifestyle and thus to reducing the environmental destruction. The change in the mindset is a long-term process, but it can be accomplished.

\section{References}

[1] Dąbrowska, A., Janoś-Kresło, M., 2019. Ustugi jako wspótczesny kreator konsumpcjonizmu (Services as a Contemporary Creator of Consumerism) In: Mróz, B. (ed.), 2019. Oblicza konsumpcjonizmu (Faces of Consumerism). Warsaw: Szkoła Główna Handlowa (Warsaw School of Economics), p.52.

[2] Grudzewski, W., Hejduk, I.K., Sankowska, A., Wańtuchowicz, M., 2010. Sustainability $w$ biznesie, czyli przedsiębiorstwo przyszłości zmiany paradygmatów i koncepcji zarzadzania (Sustainability in Business - Enterprise of the Future - Changes in Paradigms and Management Concepts). Warsaw: Poltext.

[3] Huma, M., 2013. Odpowiedzialna konsumpcja (Responsible Consumption), [online] Available at: http://www.ekonsument.pl/a105_odpowiedzi 
alna_konsumpcja.html [Accessed 22 February 2013].

[4] Kotler, P., Kartajaya, H., Setiawan, I., 2010. Marketing 3.0: from Products to Customers to the Human Spirit, Hoboken.

[5] Mróz, B., 2009. Consumo ergo sum? Rola konsumpcjonizmu we wspótczesnych spoteczeństwach (The Role of Consumerism in Contemporary Societies). In: Mróz, B. (red.), Oblicza konsumpcjonizmu (Faces of Consumerism). Warsaw: Szkoła Główna Handlowa (Warsaw School of Economics).

[6] Obesity - Special report, 2012. The Economist, December 15.

[7] Spreckley, F., 1981. Social Audit. A Management Tool for Co-operative Working. Beechwood College, UK.
[8] Szul, E., 2016. Prosumpcja jako aktywność wspótczesnych konsumentów - uwarunkowania I przejawy (Prosumption as Activity of Contemporary Consumers - Determinants and Manifestations), [online] Available at: www.ur.edu.pl [Accessed 25 April 2016].

[9] Szymusiak, T., 2015. Prosument - Prosumpcja Prosumeryzm. Ekonomiczne oraz spoleczne korzyści prosumpcji na przykładzie Polski oraz Niemiec (podejście naukowe) (Prosumer Prosumption - Prosumerism. Economic and Social Benefits of Prosumption on the Example of Germany and Poland (Scientific Approach)), Warsaw: Publisher Bezkresy Wiedzy. 